\title{
miR-21: A gene of dual regulation in breast cancer
}

\author{
CHUNFU ZHANG ${ }^{1}$, KUI LIU ${ }^{2}$, TAO LI $^{2}$, JIE FANG $^{3}$, YANLING DING ${ }^{2}$, LINGXIAN SUN $^{2}$, TAO TU $^{2}$, \\ XINYI JIANG ${ }^{2}$, SHANMEI DU ${ }^{5}$, JIABO HU ${ }^{2}$, WEI ZHU ${ }^{2},{\text { HUABIAO } \mathrm{CHEN}^{2,4} \text { and XIAOCHUN SUN }}^{2}$ \\ ${ }^{1}$ The Second People's Hospital of Kunshan, Kunshan, Jiangsu 215300; ${ }^{2}$ School of Medicine, Jiangsu University, Zhenjiang, \\ Jiangsu 212013; ${ }^{3}$ Affiliated Hospital of Jiangsu University, Zhenjiang, Jiangsu 212001, P.R. China; \\ ${ }^{4}$ Vaccine and Immunotherapy Center, Massachusetts General Hospital and Harvard Medical School, \\ Boston, MA 02114, USA; ${ }^{5}$ Zibo Vocational Institute, Zibo, Shandong 255314, P.R. China
}

Received August 15, 2015; Accepted October 1, 2015

DOI: 10.3892/ijo.2015.3232

\begin{abstract}
Breast cancer is characterized by an elevated capacity for tumor invasion and lymph node metastasis, but the cause remains to be determined. Recent studies suggest that microRNAs (miRNAs) can regulate the evolution of malignant behavior by regulating multiple target genes. A key oncomir in carcinogenesis is miR-21, which is consistently upregulated in a wide range of cancers. However, few functional studies are available for miR-21, and few targets have been identified. In this study, we explored the role of miR-21 in human breast cancer cells and searched for miR-21 targets. Total RNA from breast cancer tissue and corresponding adjacent normal tissue was extracted and used to detect miR-21 expression by quantificational real-time polymerase chain reaction (qRT-PCR), followed by analysis of the correlation between gonad hormone indices in peripheral blood and miR-21 expression in cancerous tissues from the same patients. Cell proliferation, colony formation, migration and invasion were then examined to determine the role of miR-21 in regulating breast cancer cells. Finally, western blotting was performed to determine if miR-21 regulated expression of signal transducers and activators of transcription 3 (STAT3), and assays of cell proliferation, colony formation, migration and invasion were performed to examine the role of STAT3 in regulation of breast cancer cells. We found that expression of miR-21 increased from normal through benign to cancerous breast tissues. Enhanced miR-21 expression was associated with serum levels of follicle-stimulating hormone, estradiol,
\end{abstract}

Correspondence to: Dr Xiaochun Sun, School of Medical Science and Laboratory Medicine, Jiangsu University, 301 Xuefu Road, Zhenjiang, Jiangsu 212013, P.R. China

E-mail: xiaochun@ujs.edu.cn

Professor Huabiao Chen, Vaccine and Immunotherapy Center, Massachusetts General Hospital and Harvard Medical School, Boston, MA 02114, USA

E-mail: huabiao.chen@mgh.harvard.edu

Key words: breast cancer, miR-21, proliferation, migration, STAT3 $\beta$-human chorionic gonadotropin, testosterone and prolactin in patients with breast cancer. Furthermore, cell proliferation, colony formation, migration and invasion were increased after overexpression of miR-21 in breast cancer cells and reduced by miR-21 suppression. In addition, we identified a putative miR-21 binding site in the 3'-untranslated region of the STAT3 gene using an online bioinformatical tool. We found that protein expression of STAT3 was significantly downregulated when breast cancer cells were transfected with miR-21 mimics, and was significantly upregulated in breast cancer cells transfected with a miR-21 inhibitor. Finally, we found that cell proliferation, colony formation, migration and invasion were decreased by treatment with $2.5 \mathrm{nM}$ of Stattic, an inhibitor of STAT3 activation. Our data suggest that miR-21 expression is increased in breast cancer and plays an important role as a tumor gene by targeting STAT3, which may act as a double-response controller in breast cancer.

\section{Introduction}

Breast cancer is a common female malignant tumor and a major threat to health of women. As many as 1.2 million women worldwide are diagnosed with breast cancer each year, and approximately 500,000 women die each year of this malignancy (1). The incidence of breast cancer accounts for $7-8 \%$ of the total number of malignant tumors (2). Therefore, research and development of treatments targeting breast cancer is of great importance.

miRNAs are endogenous, noncoding small RNAs 20-25 nucleotides in length (3). They play an important regulatory role through complimentary binding of the 3 ' untranslated region (UTR) of target genes resulting in the degradation of the target mRNA and inhibition of translation (4). Since the discovery of miRNAs in 1993 (5), they have been shown to affect multiple cellular processes (6), and in particular, have been shown to play significant roles in cancer development and progression $(7,8)$. Aberrant expression of miRNAs has been implicated in human carcinogenesis and cancer progression (9-13) indicating that some miRNAs can function as either tumor suppressor genes or oncogenes. For example, upregulation of several miRNAs in breast cancer cells increased tumor cell invasion and metastasis $(14,15)$, whereas expression of 
miR-31 and miR-335 inhibited breast cancer cell invasion and metastasis $(16,17)$. In this study, we first confirmed using qRT-PCR that expression of miR-21 in breast cancer tissue was enhanced compared to corresponding adjacent normal tissue, then assessed the role of miR-21 in breast cancer cell lines. Finally, western blotting demonstrated that miR-21 regulated STAT3 protein expression which in turn contributed to tumor formation.

\section{Materials and methods}

Breast tissue specimens. Documented informed consent was obtained from all subjects and the Ethics Committee of Jiangsu University (Zhenjiang, Jiangsu Province, China) approved all aspects of the study. Two cohorts of clinical specimens including breast cancer tissues and corresponding adjacent normal tissues were obtained from 30 female patients with breast cancer at the Department of Surgery, the Second People's Hospital of Kunshan, China. Both tumor tissues and corresponding adjacent normal tissues were histologically confirmed. Clinical characteristics of patients are listed in Table I. Tissue specimens were placed in cryovials, snap-frozen and stored at $-80^{\circ} \mathrm{C}$ immediately after operation until use. Data on levels of patient hormones including follicle-stimulating hormone (FSH), estradiol, $\beta$-human chorionic gonadotropin (HCG), testosterone and prolactin were provided by the Second People's Hospital of Kunshan, China. The protocol for the use of patient samples in this study was approved by the institutional review board of the hospital and informed consent was obtained from each patient or guardian.

Cell lines and culture. The human breast cancer cell lines MCF-7 and MDA-MB-231 were obtained from Nanjing University (Nanjing, Jiangsu Province, China). The cells were grown in Dulbecco's modified Eagle's medium (DMEM) (Gibco BRL Co. Ltd., USA) with low glucose (L-DMEM) supplemented with $10 \%$ fetal bovine serum (FBS, ExCell Biology, Shanghai, China) at $37^{\circ} \mathrm{C}$ in a humidified incubator containing $5 \% \mathrm{CO}_{2}$.

Transient miRNA transfection. The MCF-7 and MDA-MB-231 cells were selected for miR-21 transfection. miR-21 mimics, mimics negative control (mimics NC), miR-21 inhibitor and inhibitor negative control (inhibitor NC) were synthesized and purified by Genepharma (Shanghai, China). Sequences are listed in Table II. Briefly, the cells were grown overnight and then transfected with $100 \mathrm{nM}$ of miR-21 mimics, miR-21 inhibitor or negative control miRNA using Lipofectamine ${ }^{\circledR} 2000$ (Invitrogen, Thermo Fisher Scientific Inc. Waltham, MA, USA) according to the manufacturer's protocol.

Suppression of phosphorylated STAT3. Stattic, a small molecule inhibitor of STAT3 phosphorylation and activation, was obtained from Selleck Chemicals (Houston, TX, USA). The MCF-7 and MDA-MB-231 cells were seeded into 6-well plates and Stattic, at $2.5 \mathrm{nM}$, was used to suppress phosphorylated STAT3 (p-STAT3) according to the manufacturer's instructions.

RNA isolation and $q R T-P C R$. To detect miR-21 expression, total RNA from tissues samples and cell lines transfected
Table I. Clinical characteristics of patients.

Characteristic

Number $(\%)$

$\begin{array}{lr}\text { Age, years } & \\ <60 & 24(80) \\ >60 & 6(20)\end{array}$

Type

Invasive ductal carcinoma

Intraductal carcinoma

Adenocarcinoma infiltrating

ER

Positive

Negative

PR

Positive

Negative

Her-2

Positive

Negative

ER, estrogen receptor; PR, prolactin receptor.

with miR-21 mimics, inhibitor or negative controls for $24 \mathrm{~h}$, was extracted using TRIzol reagent (Invitrogen, Thermo Fisher Scientific Inc.) according to the manufacturer's instructions, then reverse transcribed into cDNA using reverse transcriptase (GenePharma). qRT-PCR was performed using a SYBR green-containing PCR kit (GenePharma) according to the manufacturer's instructions with the CFX-96 real-time fluorescence thermal cycler (Bio-Rad, CA, USA). The PCR amplification consisted of 40 cycles $\left(95^{\circ} \mathrm{C}\right.$ for $12 \mathrm{sec}, 62^{\circ} \mathrm{C}$ for $40 \mathrm{sec}$ ) after an initial denaturation at $95^{\circ} \mathrm{C}$ for $3 \mathrm{~min}$. The relative expression levels of $\mathrm{miR}-21$ were normalized to the expression of U6snRNA. The threshold cycle $(\mathrm{Ct})$ was defined as the fractional cycle number at which fluorescence intensity passed a fixed threshold. The fold change in miR-21 expression was calculated using the $2^{-\Delta \mathrm{Ct}}$ method relative to U6 snRNA. All experiments were performed in triplicate. Primer sequences are listed in Table III.

Cell proliferation assay. Twenty-four hours after transient transfection with miR-21 mimics, inhibitor or negative controls, with and without Stattic suppression of p-STAT3, MCF-7 and MDA-MB-231, cells were harvested and sub-cultured in 96-well plates. Cell proliferation was assessed using thiazolyl blue tetrazolium bromide (MTT, Amresco, USA) according to the manufacturer's instructions. Briefly, MTT reagent $(20 \mu \mathrm{l})$ was added to each well and incubated at $37^{\circ} \mathrm{C}$ for $4 \mathrm{~h}$. The reagent was then removed and dimethyl sulfoxide $(150 \mu \mathrm{l})$ was added to each well. Absorbance at $492 \mathrm{~nm}$ was measured using an FLx800 Fluorescence Microplate Reader (Biotek, VT, USA). The experiment was performed on triplicate wells and repeated three times. The data were summarized as means \pm standard error of the mean (SEM). 
Table II. Sequence of miR-21 mimics, miR-21 inhibitor and negative controls.

\begin{tabular}{lll}
\hline Name & & \multicolumn{1}{c}{ Sequence } \\
\hline miR-21 mimics & Sense & 5'-UAGCUUAUCAGACUGAUGUUGA -3' \\
& Antisense & 5'-AACAUCAGUCUGAUAAGCUAUU-3' \\
Mimics negative control & Sense & 5'-UUCUCCGAACGUGUCACGUTT-3' \\
& Antisense & 5'-ACGUGACACGUUCGGAGAATT-3' \\
miR-21 inhibitor & & 5'-UCAACAUCAGUCUGAUAAGCUA-3' \\
Inhibitor negative control & & 5'-CAGUACUUUUGUGUAGUACAA-3' \\
\hline
\end{tabular}

Table III. Specific primers for target and control genes.

\begin{tabular}{ll}
\hline Name & \multicolumn{1}{c}{ Sequence } \\
\hline miR-21 forward primer & 5'-ACGTTGTGTAGCTTATCAGACTG-3' \\
miR-21 reverse primer & 5'-AATGGTTGTTCTCCACACTCTC-3' \\
U6snRNA forward primer & 5'-ATTGGAACGATACAGAGAAGATT-3' \\
U6snRNA forward primer & 5'-GGAACGCTTCACGAATTTG-3' \\
\hline
\end{tabular}

Colony-forming assay. The MCF-7 and MDA-MB-231 cells were transfected as described above in the presence and absence of Stattic for $6 \mathrm{~h}$, seeded into 6 -well plates $\left(0.5 \times 10^{3}\right.$ cells/well $)$ and incubated for 10 days. Cells were then fixed and stained, followed by colony counting. The experiment was performed in triplicate, with data summarized as means \pm SEM.

Wound healing assay. The MCF-7 and MDA-MB-231 cells were seeded into 6-well plates, transiently transfected as previously described with and without Stattic, then allowed to grow until $100 \%$ confluent. The cell layer was then scratched through the central axis using a sterile plastic tip and loose cells were washed away by phosphate buffer saline (PBS). Wound healing was observed and photographed at 0 and $48 \mathrm{~h}$ in three randomly selected microscopic fields for each condition and time-point. The degree of motility $48 \mathrm{~h}$ after confluent cells had been scratched was expressed as the percentage of wound closure calculated as follows: (Distance of cell migration at $48 \mathrm{~h} /$ distance of scratch at $0 \mathrm{~h}$ ) $\times 100 \%$. The experiment was performed in triplicate and data were summarized as means \pm SEM.

Cell invasion assay. Cell invasion assays were carried out using Transwell inserts (Corning, VA, USA). The MCF-7 and MDA-MB-231 cells were transiently transfected as previously described with and without Stattic inhibition of p-STAT3. Beginning $48 \mathrm{~h}$ after the start of transfection, cells were starved in L-DMEM without FBS for $2 \mathrm{~h}$, and $4 \times 10^{4}$ cells were resuspended in $0.1 \mathrm{ml}$ L-DMEM without FBS and seeded in the upper chamber of a Transwell insert. Then L-DMEM, containing $20 \%$ FBS, was added to the lower chamber as a chemoattractant. To measure the effect of miR-21 mimics or miR-21 inhibitor on MCF-7 and MDA-MB-231 invasion potential, the cells in the upper chamber were cultured for
$14 \mathrm{~h}$ (MDA-MB-231) or $16 \mathrm{~h}$ (MCF-7) at $37^{\circ} \mathrm{C}$ in humidified $5 \% \mathrm{CO}_{2}$. Cells which had invaded to the lower chamber were fixed and stained with $0.1 \%$ crystal violet. Three low-magnification areas (x100) were randomly selected and the number of migrated cells was counted. All experiments were performed in triplicate, and data were summarized as means \pm SEM.

Protein extraction and western blot analysis. Cells were transiently transfected as previously described in the presence and absence of Stattic. Cells were washed twice with PBS after $48 \mathrm{~h}$ and total cellular protein was extracted using a modified radioimmunoprecipitation assay lysis buffer (Vazyme, Nanjing, China) supplemented with $100 \mathrm{mM}$ phenylmethanesulfonyl fluoride (Beyotime, Shanghai, China). The protein concentration was determined using a NanoDrop 1000 Spectrophotometer (Thermo Scientific, MA, USA). Equal amounts of protein lysates $(100 \mu \mathrm{g})$ were separated by $10 \%$ sodium dodecyl sulfate polyacrylamide gel electrophoresis (Beyotime) and then transferred to polyvinylidene fluoride membranes (Beyotime). The membranes were blocked with $5 \%$ defatted milk/Tris-buffered saline $(20 \mathrm{mM}$ Tris- $\mathrm{HCl}$ pH 7.4, 150 mM NaCl, with $0.1 \%$ Tween-20; Tris-buffered saline with Tween-20, TBST) at room temperature for $1 \mathrm{~h}$ and incubated with primary antibodies at $4^{\circ} \mathrm{C}$ overnight. The antibodies were anti-STAT3 $(1: 1,000)$, anti-p-STAT3 $(1: 1,000)$, and anti-glyceraldehyde 3 -phosphate dehydrogenase $(1: 1,000)$, all purchased from Cell Signaling Technology (Boston, MA, USA). The next day, the membranes were washed with TBST, then incubated with horseradish peroxidase-linked secondary antibody (anti-rabbit IgG, 1:1,000, Cell Signaling Technology). The protein bands were developed with enhanced chemiluminescence reagents (Beyotime).

Statistical analysis. For statistical analyses, mean values \pm SEM were generated from several repeats of each experiment. The P-values were obtained from t-tests with paired or unpaired samples and $\mathrm{P}<0.05$ was considered statistically significant. The correlation between miR-21 expression and hormones was analyzed used Spearman correlation and $\mathrm{P}<0.05$ was considered significant.

\section{Results}

miR-21 is increased in breast cancer tissues. We performed qRT-PCR to determine miR-21 levels in 30 breast cancer 

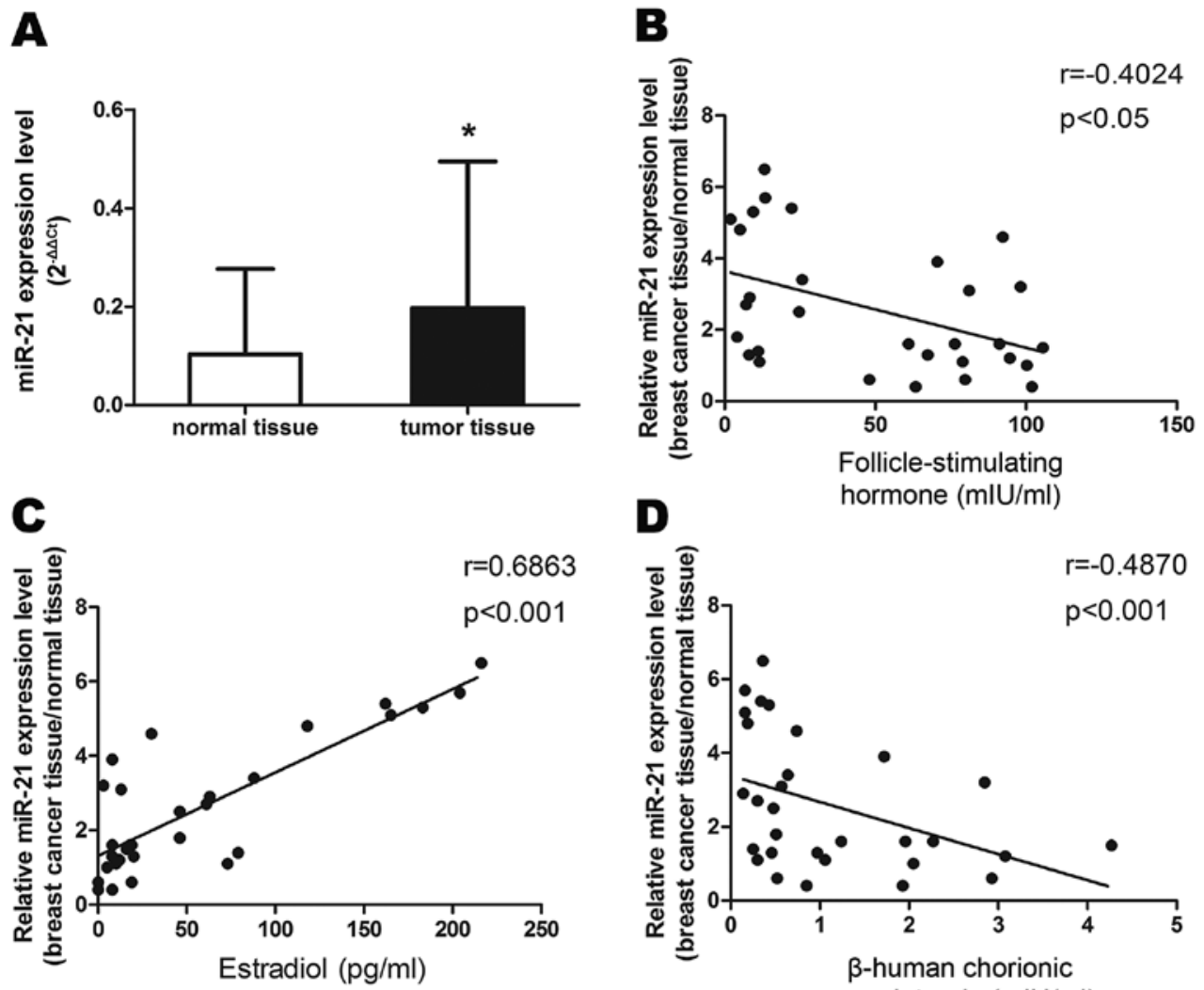

D hormone $(\mathrm{mlU} / \mathrm{ml})$
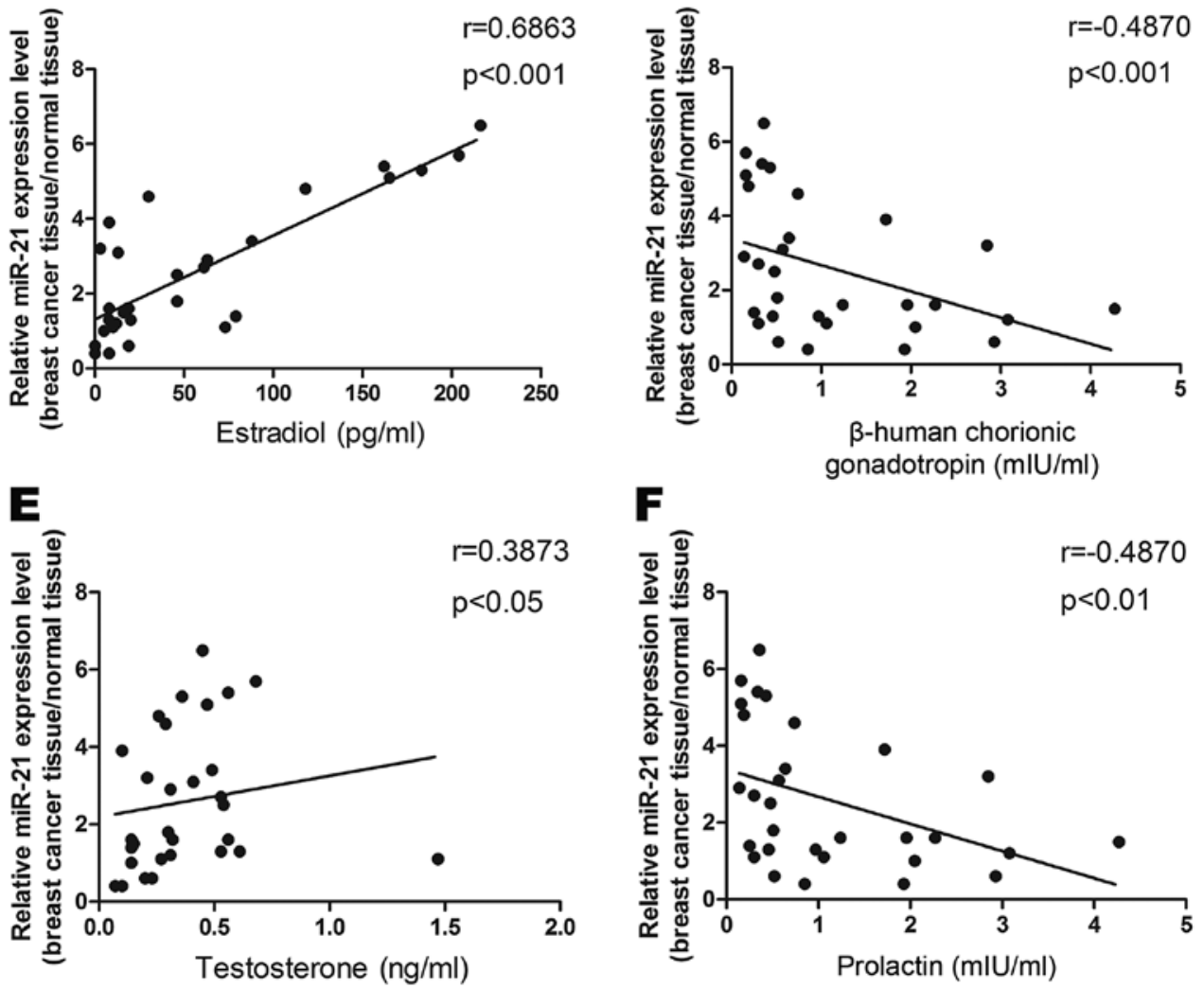

Figure 1. miR-21 levels in breast cancer tissues and correlation analyses with hormone levels. (A) Expression of miR-21 was analyzed by qRT-PCR. The expression level of miR-21 was significantly increased in breast cancer tissues compared to adjacent normal tissues. The graph displays the mean of $2^{-\mathrm{ACt}}$ values \pm SEM ( $(\mathrm{P}<0.05)$. (B-F) Correlation between the ratio of miR-21 expression in the breast cancer tissues compared to adjacent normal tissues and serum levels of FSH (B), estradiol (C), HCG (D), testosterone (E), and prolactin (F) in patients (n=30). The r-values were calculated by Spearman correlation analysis.

tissues and adjacent normal breast tissues. As shown in Fig. 1A, expression of miR-21 was upregulated in cancer tissues compared to adjacent normal tissues. We then examined the association of miR-21 expression with corresponding clinicopathological data from the breast cancer patients. We observed that increased miR-21 expression was associated with decreased serum levels of FSH $(r=-0.4024, \mathrm{P}<0.05), \mathrm{HCG}$ $(\mathrm{r}=-0.487, \mathrm{P}<0.001)$ and prolactin $(\mathrm{r}=-0.487, \mathrm{P}<0.01)$, and with increased levels of estradiol $(\mathrm{r}=0.6863, \mathrm{P}<0.01)$ and testosterone $(\mathrm{r}=0.3873, \mathrm{P}<0.05)$ in patients with breast cancer (Fig. 1B-F). To confirm the function of miR-21, we transfected miR-21 mimics, inhibitor or negative control sequences into breast cancer cell lines MCF-7 and MDA-MB-231. Transfection efficiency was estimated by fluorescence microscopy $6 \mathrm{~h}$ after transfection (Fig. 2A) and miR-21 expression level was verified by real-time PCR (Fig. 2B-E). We found that miR-21 mimics significantly increased miR-21 RNA expression while the miR-21 inhibitor significantly decreased miR-21 RNA expression in both breast cancer cell lines.

miR-21 promotes breast cancer cell proliferation. To further examine the functional aspects of miR-21 expression, we performed gain-of-function and loss-of-function analyses in MCF-7 and MDA-MB-231 cells as models of breast cancer. Cells were transfected with miR-21 mimics, inhibitor or negative controls and measured the absorbance at $492 \mathrm{~nm}$. Compared with the treatment with the mimics NC, cell proliferation was promoted when cells were treated with 
A

MCF-7

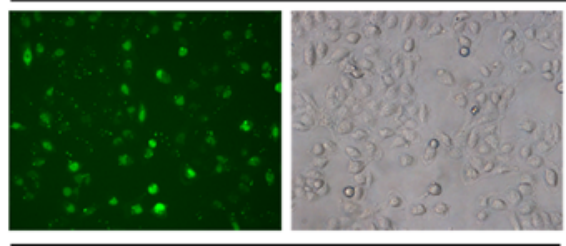

mimics

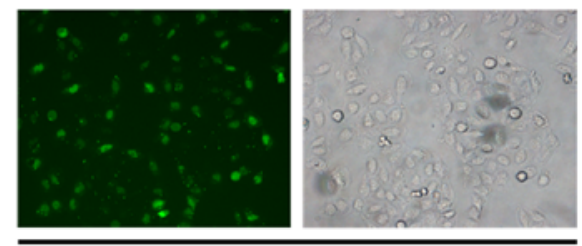

inhibitor

MDA-MB-231

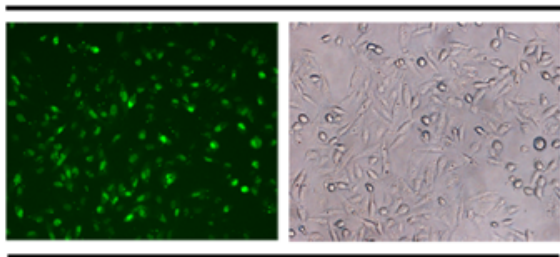

mimics

$\mathbf{B}$

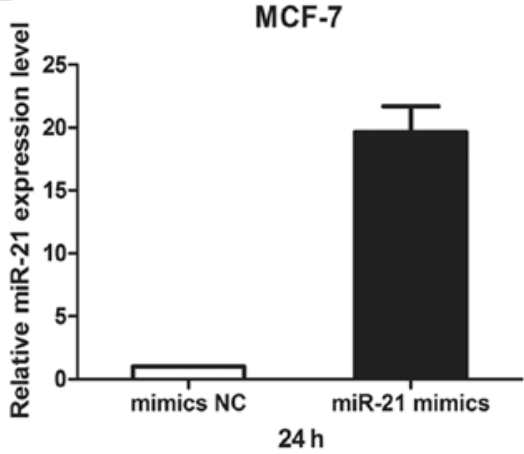

D

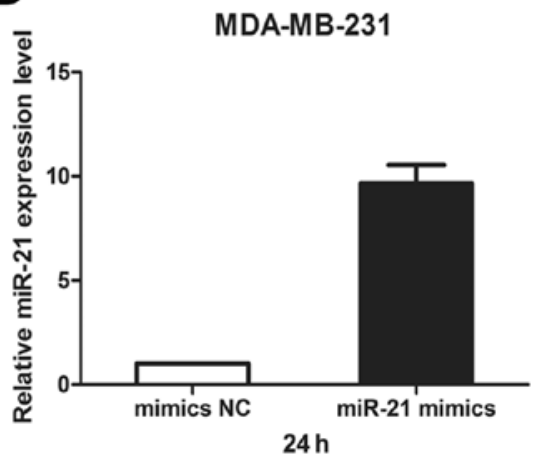

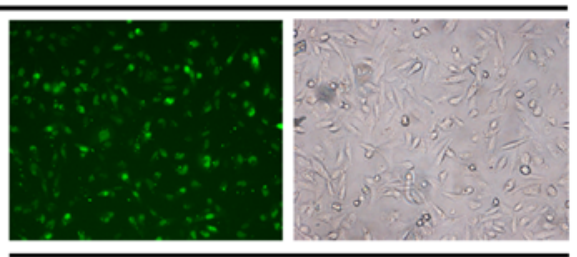

inhibitor
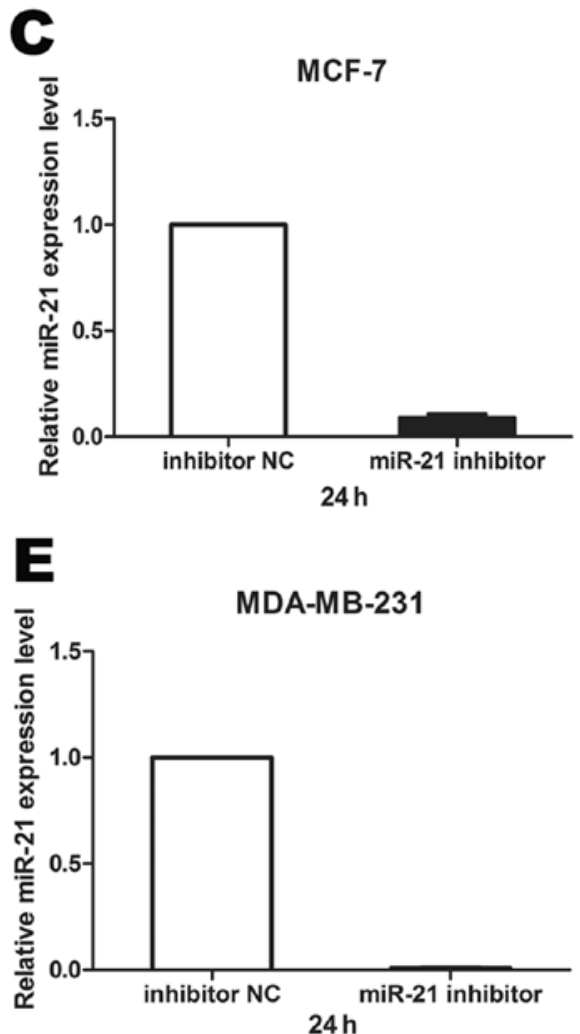

Figure 2. The effect of miR-21 mimics and inhibitor on miR-21 expression in transfected breast cancer cells. The MCF-7 and MDA-MB-231 breast cancer cells were transiently transfected with miR-21 mimics, miR-21 inhibitor or negative controls (NC). (A) Transfection efficiency of MCF-7 cells (top panels) and MDA-MB-231 cells (bottom panels) was estimated by fluorescein (FAM) fluorescence microscopy (x200) $6 \mathrm{~h}$ after transfection with miR-21 mimics or miR-21 inhibitor, presented as FAM-expressing cells (left image of each pair) and differential interference contrast images (right image of each pair). (B-E) qRT-PCR was used to investigate miR-21 expression after transfection. miR-21 expression relative to U6 snRNA was significantly increased or decreased in response to miR-21 mimics or miR-21 inhibitor, respectively, in MCF-7 cells (B and C) and MDA-MB-231 cells (D and E) compared to their negative controls (mimics NC or inhibitor NC).

miR-21 mimics. Compared with the inhibitor NC treatment, cell proliferation was inhibited when cells were treated with miR-21 inhibitor $(\mathrm{P}<0.05, \mathrm{P}<0.01, \mathrm{P}<0.001)$ (Fig. 3).

miR-21 promotes breast cancer cell colony formation. Colonies formed from miR-21 mimic transfected cells were significantly more than from the mimics NC transfected cells.
The miR-21 inhibitor transfected cells formed significantly less colonies than that of inhibitor NC transfected cells $\left({ }^{* *} \mathrm{P}<0.01\right.$, (Fig. 4). These data demonstrated that miR-21 promoted breast cancer cell colony formation.

miR-21 promotes breast cancer cell migration. Cell scratch assay showed that cells transfected with miR-21 mimics 

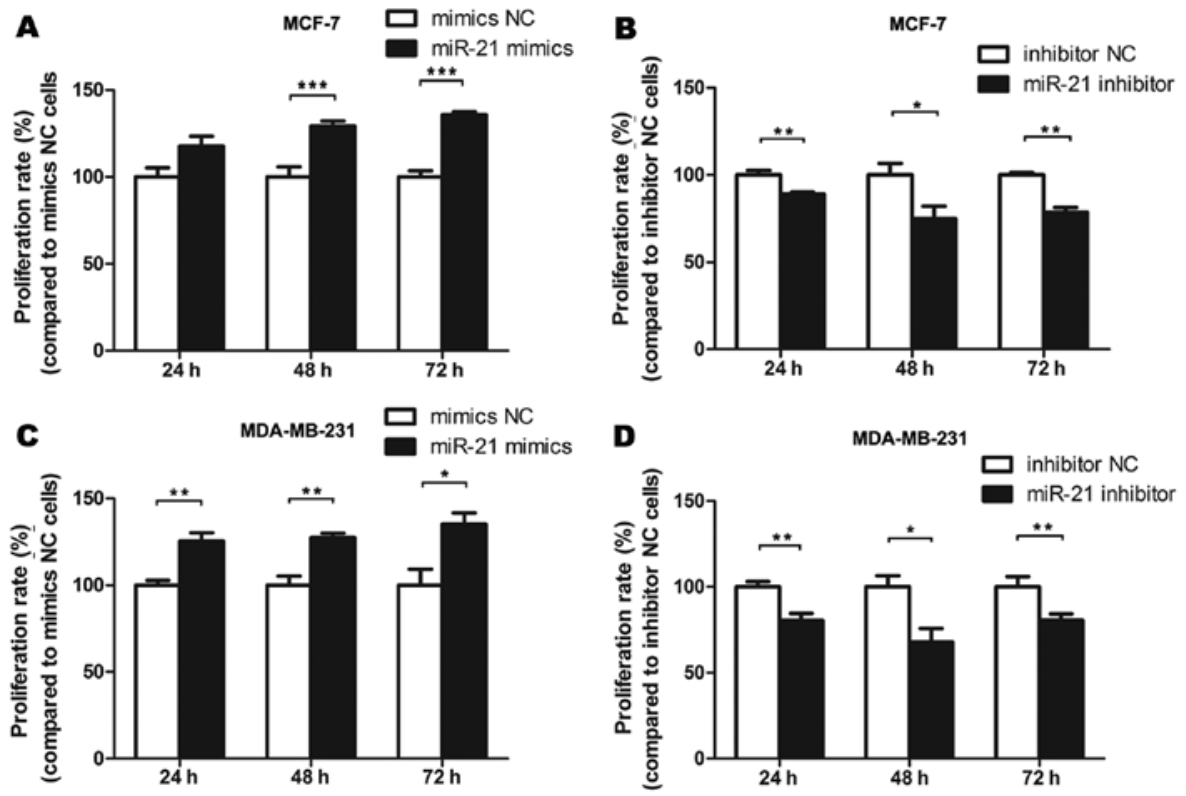

Figure 3. miR-21 promoted cell proliferation of breast cancer cell lines. The proliferation of breast cancer cells lines MCF-7 (A and B); MDA-MB-231 (C and D) transfected with miR-21 mimics or miR-21 inhibitor was examined at 24, 48 and $72 \mathrm{~h}$ by MTT assays. The graphs display the relative proliferation rates of cells transfected with miR-21 mimics (A and C) or miR-21 inhibitor (B and D) compared to their negative controls (mimics NC or inhibitor NC) shown as mean percentage \pm SEM. ${ }^{*} \mathrm{P}<0.05,{ }^{* *} \mathrm{P}<0.01,{ }^{* * *} \mathrm{P}<0.001$.

$\mathbf{A}$

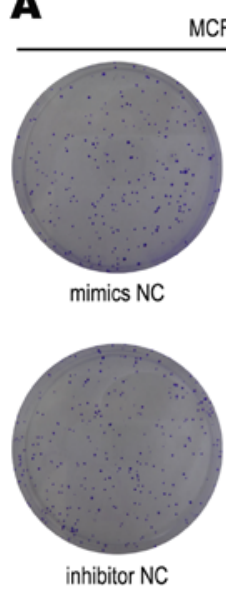

B

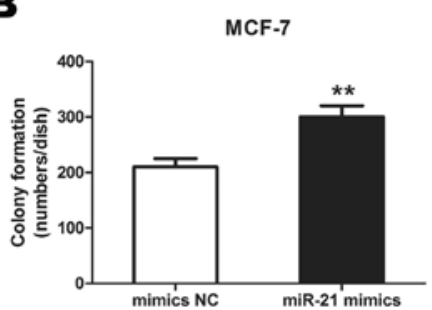

D

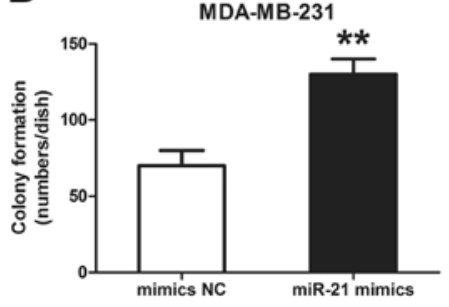

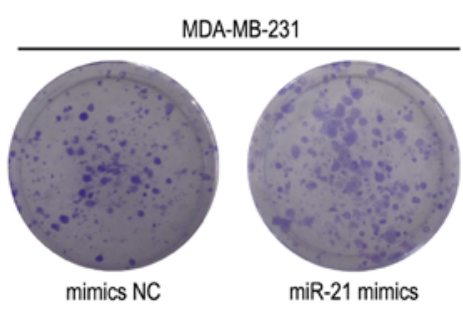

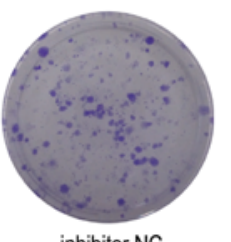

inhibitor NC

C

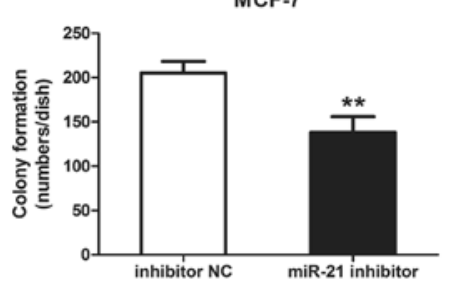

E

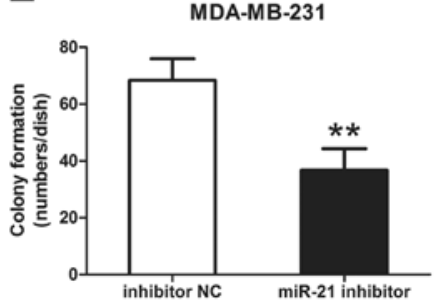

Figure 4. miR-21 promoted breast cancer cell colony formation. (A) Representative examples of colonies of breast cancer cells (MCF-7, left panels; MDAMB-231, right panels) transfected with miR-21 mimics, inhibitor or negative controls stained by crystal violet at day 10 post-transfection. The graphs display the mean colony number \pm SEM for MCF-7 cells transfected with mimics and inhibitors (B and C, respectively) and MDA-MB-231 cells similarly transfected (D and E, respectively). ${ }^{* *} \mathrm{P}<0.01$. 
$\mathbf{A}$

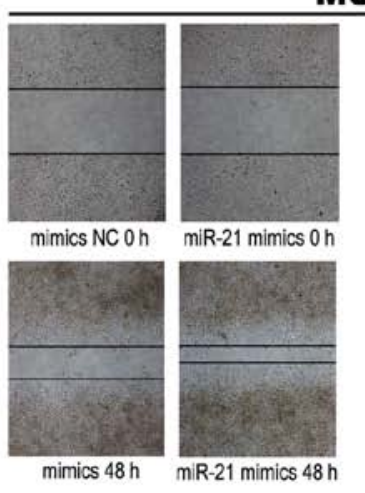

B

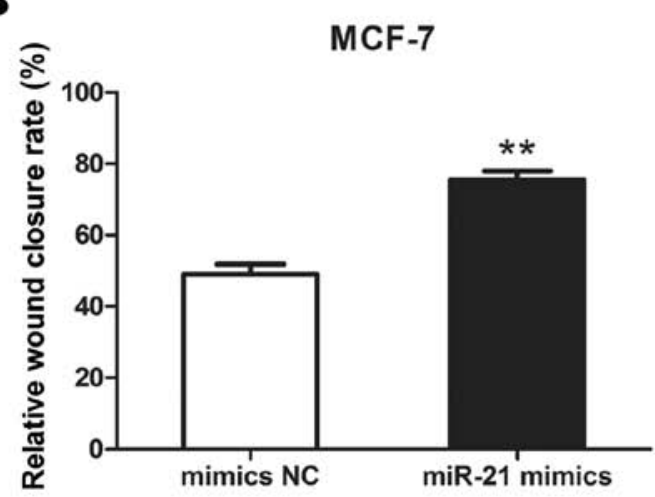

D

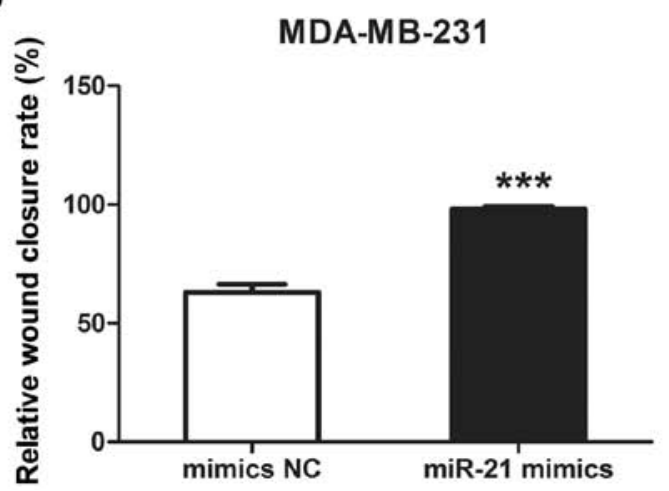

MCF-7
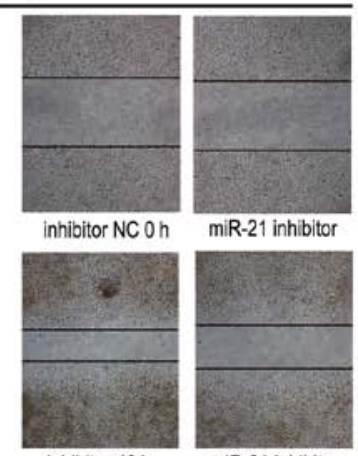

inhibitor $48 \mathrm{~h}$ miR-21 inhibitor

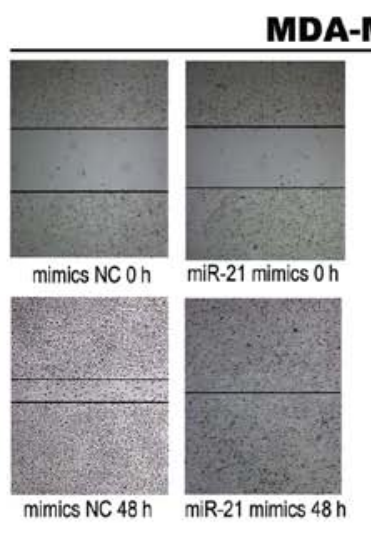

C
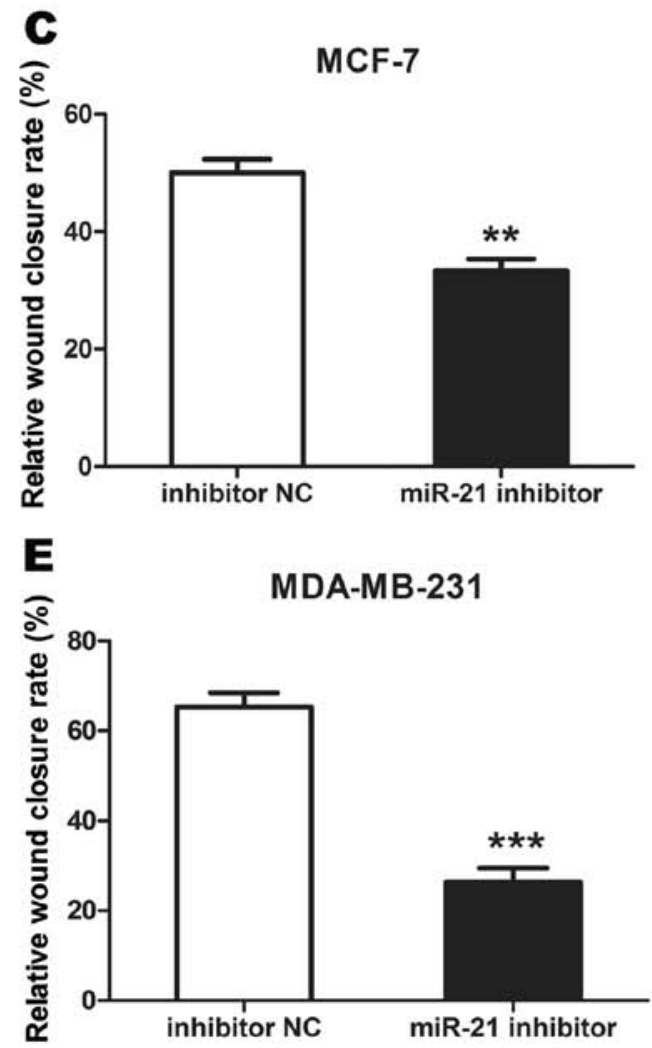

Figure 5. miR-21 promoted breast cancer cell migration. The migration of breast cancer cells transfected with miR-21 mimics or miR-21 inhibitor was examined by the cell scratch assay. (A) Representative images of MCF-7 cells (left panels) and MDA-MB-231 cells (right panels) taken at 0 and 48 h after confluent cells had been scratched. The distance between the migrating fronts of the scratch was measured in three randomly selected microscopic fields for each condition and time-point (x100). The graphs display the mean wound closure rates \pm SEM for MCF-7 cells transfected with mimics or inhibitor (B and C, respectively and similarly transfected MDA-MB-231 cells ( $\mathrm{D}$ and $\mathrm{E}$, respectively). ${ }^{* *} \mathrm{P}<0.01,{ }^{* * *} \mathrm{P}<0.001$.

migrated rapidly. The scratch in mimics NC treated cells was almost healed $48 \mathrm{~h}$ after the scratch had been made, but not in miR-21 mimics treated cells. The cells transfected with miR-21 inhibitor migrated more slowly than cells transfected with inhibitor $\mathrm{NC}(\mathrm{P}<0.01, \mathrm{P}<0.001)$ (Fig. 5). These data demonstrated that miR-21 promoted breast cancer cell migration.

miR-21 promotes breast cancer cell invasion. Transwell invasion assays showed that the number of tumor cells migrating from the chamber after treatment with miR-21 mimics was significantly more than that after treatment with mimics NC. The number of tumor cells migrating from the chamber after treatment of miR-21 inhibitor was significantly less than that after treatment with inhibitor $\mathrm{NC}$, demonstrating that miR-21 promoted tumor cell invasion $(\mathrm{P}<0.01)$ (Fig. 6).

STAT3 is a target gene of miR-21. We performed bioinformatics analyses to search for miR-21-targeted genes using the miRanda (www.microrna.org) database and found that STAT3 is targeted by miR-21. STAT3 mRNA has two potential complimentary binding sites with miR-21 within its 3'UTR (Fig. 7A). Based on these results, we performed western blot analysis to assess the impact of miR-21 on STAT3 expression. Western blots showed that STAT3 and p-STAT3 protein expression were actually decreased in breast cancer cells after treatment with miR-21 mimics and increased following miR-21 inhibitor treatment, compared to mimics NC groups or inhibitor NC 

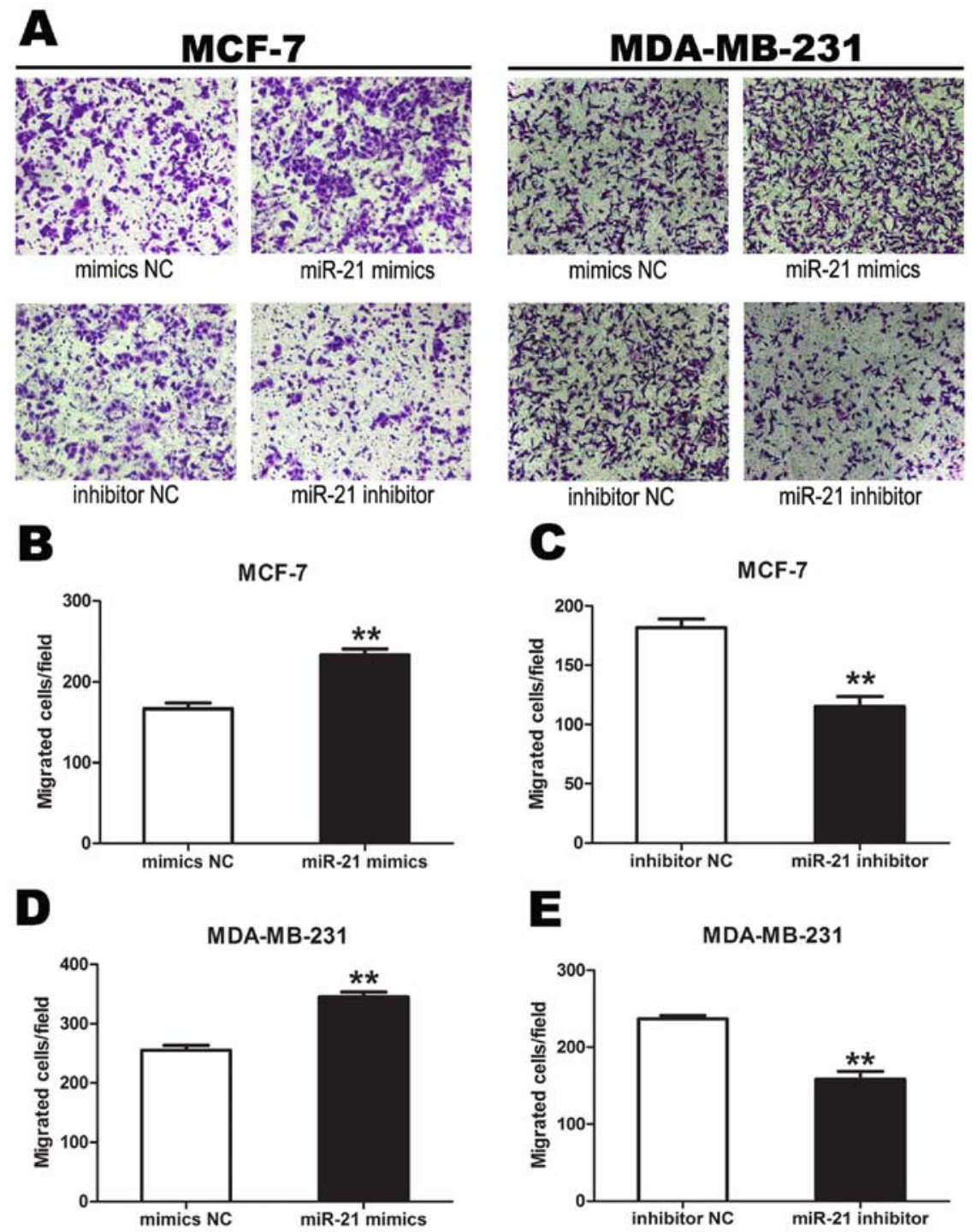

Figure 6. miR-21 promoted cell invasion by breast cancer cells. Cell invasion was analyzed by Transwell chamber assay in breast cancer cells lines transfected with miR-21 mimics or miR-21 inhibitor. (A) Representative images of crystal violet-stained migrated cells were captured $16 \mathrm{~h}$ after invasion of MCF-7 cells (left panels) and $14 \mathrm{~h}$ after invasion of MDA-MB-231 cells (right panels) using an inverted microscope with x100 magnification. (B-E) Quantification of the number of crystal violet-stained migrated MCF-7 cells (B and C) and MDA-MB-231 cells (D and E) shown as mean \pm SEM. ${ }^{* *} \mathrm{P}<0.01$.

\section{A \\ 3' aguuGUAGUCA-G-ACUAUUCGAu 5' hsa-miR-21 \\ 1930: 5' cacuCUUCAGUACAUAAUAAGCUU 3' STAT3

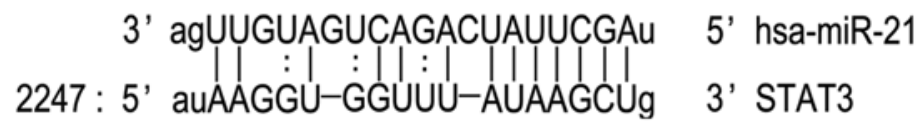

B
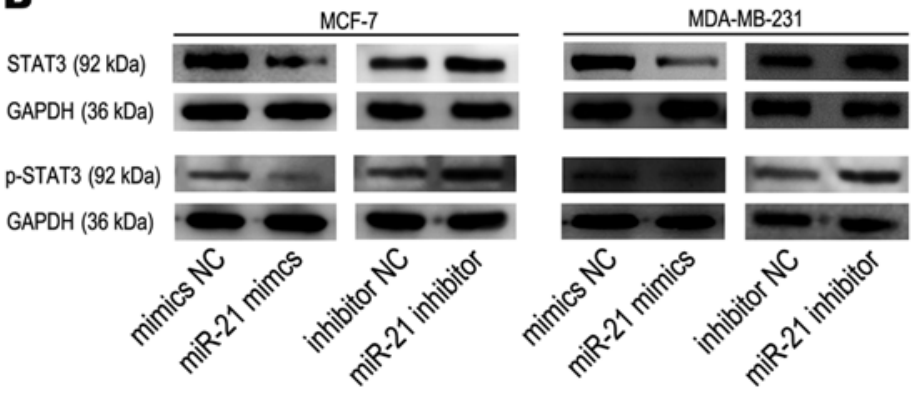

Figure 7. STAT3 is a target of miR-21 in breast cancer. (A) Schematic diagram illustrating potential miR-21 binding sites in STAT3 3'UTR mRNA predicted in silico. (B) STAT3 and p-STAT3 protein expression were analyzed by western blotting $48 \mathrm{~h}$ post-transfection in MCF-7 cells (left panels) and MDA-MB-231 cells (right panels). Glyceraldehyde 3-phosphate dehydrogenase was used as an internal control. 
$\mathbf{A}$

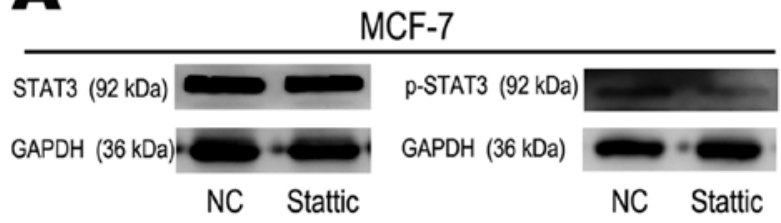

B
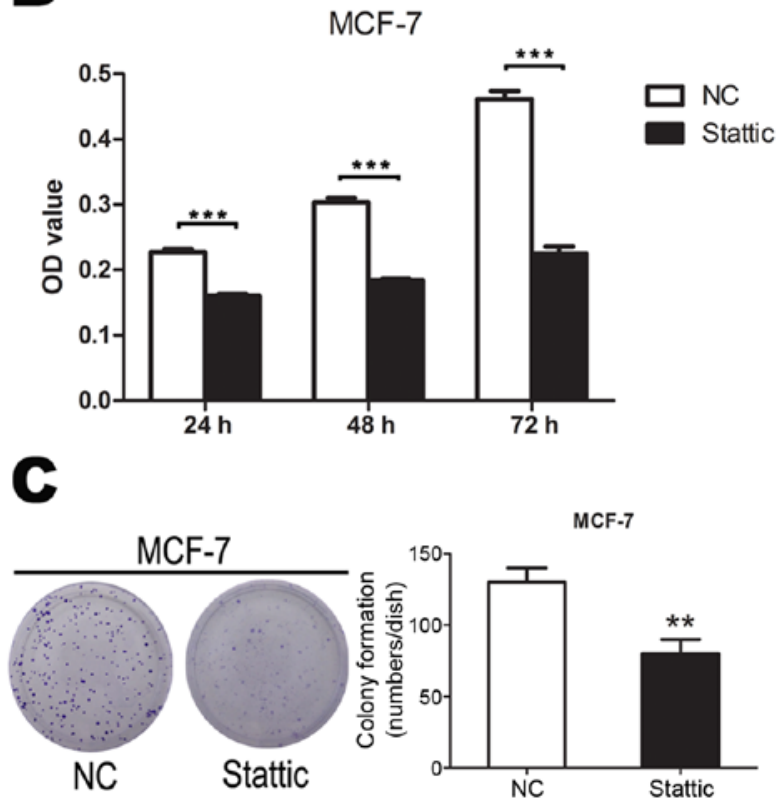

D

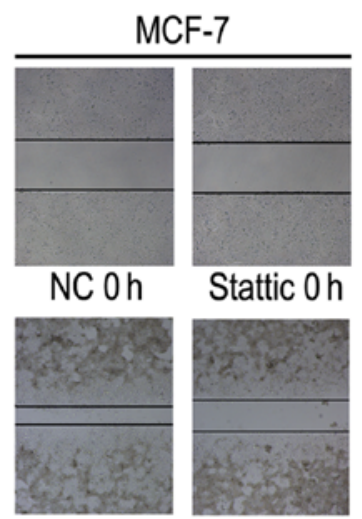

NC $48 \mathrm{~h}$ Stattic $48 \mathrm{~h}$
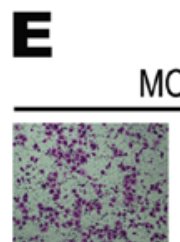

NC

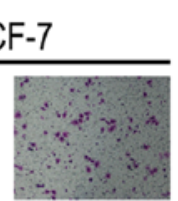

Stattic

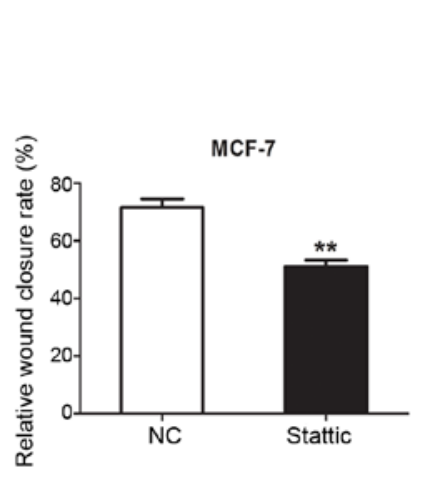

MCF-7

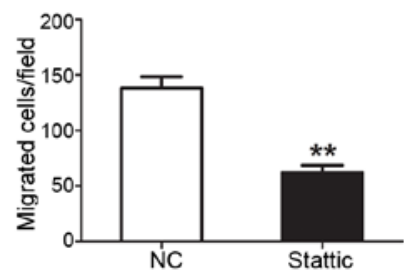

MDA-MB-231

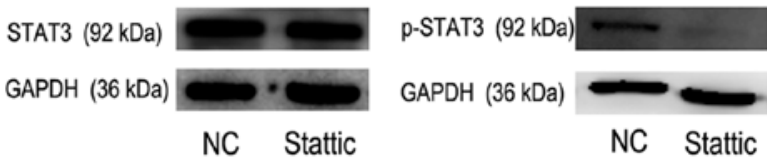

MDA-MB-231

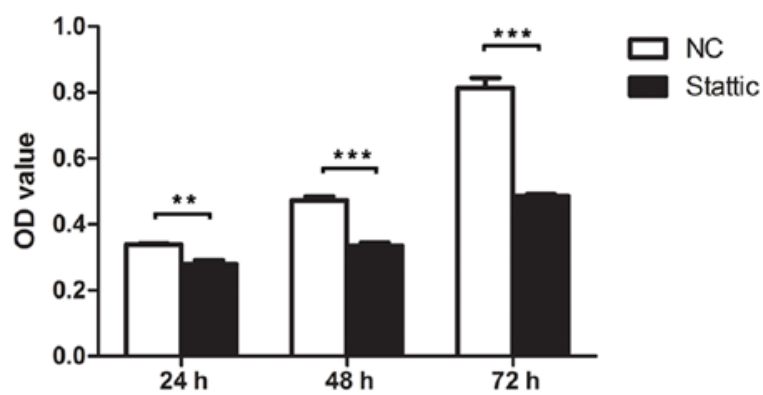

MDA-MB-231

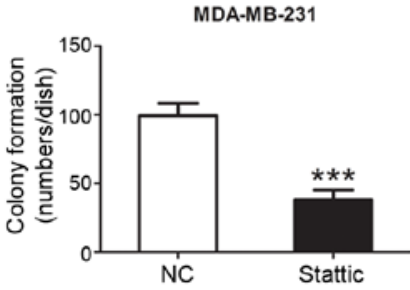

Stattic
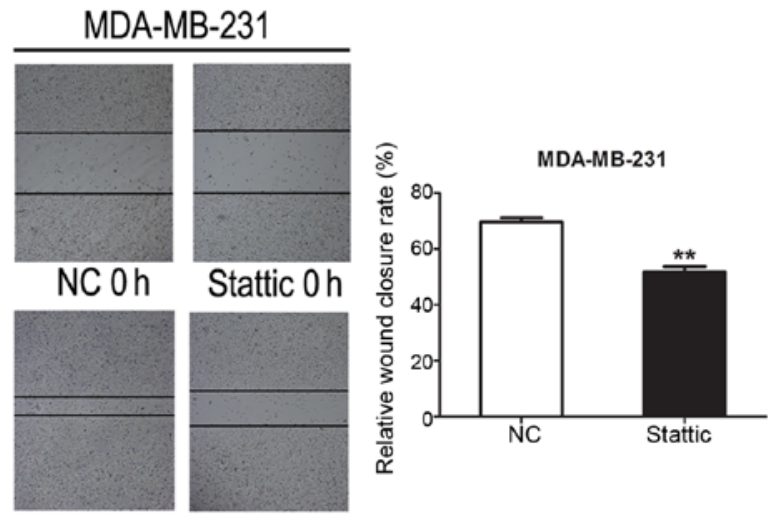

NC $48 \mathrm{~h} \quad$ Stattic $48 \mathrm{~h}$
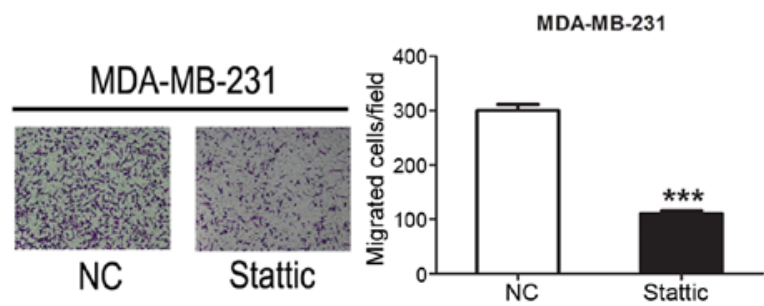

Figure 8. Inhibition of p-STAT3 reduced tumorigenic activity in breast cancer cells. (A) STAT3 and p-STAT3 protein expression were analyzed by western blotting after inhibition of p-STAT3 by Stattic in MCF-7 cells (left panels) and MDA-MB-231 cells (right panels). GAPDH was used as an internal control. (B-E) Stattic inhibited cell proliferation (B), cell colony formation (C), cell migration (D) and cell invasion (E). Charts display mean \pm SEM of triplicate experiments. ${ }^{* *} \mathrm{P}<0.01,{ }^{* * * *} \mathrm{P}<0.001$.

groups, respectively (Fig. 7B). These data show that miR-21, which increased tumorigenic activity in functional assays, may in fact target STAT3 mRNA and inhibit its translation into protein.
Phosphorylated STAT3 promotes breast cancer cell proliferation, colony formation, migration and invasion. To evaluate the effect of p-STAT3 on breast cancer cells, we suppressed p-STAT3 using Stattic inhibition of STAT3 activation 
(Fig. 8A). Compared to cells transfected with negative controls, cell proliferation were significantly suppressed when cells were treated with Stattic $(\mathrm{P}<0.001)$ (Fig. 8B). These data demonstrated that p-STAT3 inhibited breast cancer cell proliferation. Compared to cells transfected with negative controls, cell colony formation were significantly suppressed when cells were treated with Stattic $(\mathrm{P}<0.01$, $\mathrm{P}<0.001$ ) (Fig. 8C). These data demonstrated that $\mathrm{p}-\mathrm{STAT} 3$ inhibited breast cancer cell colony formation. Compared to cells transfected with negative controls, cell migration were significantly suppressed when cells were treated with Stattic $(\mathrm{P}<0.01)$ (Fig. 8D). These data demonstrated that p-STAT3 inhibited breast cancer cell migration. These data demonstrated that p-STAT3 inhibited breast cancer cell colony formation. Compared to cells transfected with negative controls, cell invasion were significantly suppressed when cells were treated with Stattic $(\mathrm{P}<0.01, \mathrm{P}<0.001)$ (Fig. 8E). These data demonstrated that p-STAT3 inhibited breast cancer cell invasion.

\section{Discussion}

The occurrence of metastasis, initiated by cancer cell migration, is the primary cause of increased cancer death rates (18). Metastatic progression is a complex and clinically daunting process (19-21). Although tumor metastasis is the main cause of mortality in patients with solid cancers, our understanding of metastatic cellular mechanisms is still limited. Discovery of biomarkers to monitor tumor metastasis for application in clinical practice would be of great benefit to clinicians to effectively control tumor metastasis, to determine the risk of recurrence and to predict patient survival.

miRNAs, as upstream regulators of gene expression, have been identified as novel candidates for diagnostic markers, prognostic indicators and therapeutic targets. Common methods for analysis of miRNA expression are northern blot, real-time PCR, microarray-based profiling and bead-based technologies in tissue specimens. We recently utilized a realtime PCR approach to screen miRNA expression and found that let-7a was downregulated in breast cancer tissue samples and cell lines (22). This suggested that let-7a might act as a tumor suppressor in breast cancer by targeting High Mobility Group AT-Hook 1.

miR-21 was one of the first miRNAs detected in the human genome. It is located on chromosome 17 in the tenth intron of the coding gene transmembrane protein 49 in a region which overlaps the gene encoding human papilloma virus (HPV16) (23). This region is the most common fragile site associated with cervical cancer and changes in miR-21 expression are important for HPV16 integration in cervical cancer. In recent years, miR-21 has become a focus of cancer research. The gene expression profile of miRNA in tumor tissues and tumor cell lines suggests that miR-21 is associated with many types of cancer (24); for example, the expression level of miR-21 is five to ten times higher in nerve glioblastoma compared to normal tissues (25). This study also found that the seventeenth region of the chromosome is amplified in breast cancer, prostate cancer, and in about half of all medulloblastomas, and that genetic amplification in tumor tissues is correlated with high expression of miR-21 (26-28). miR-21 has also been recog- nized as one of the most important biomarkers implicated in human malignancy. In recent years, high levels of miR-21 expression were reported in diverse types of malignancies including breast cancer $(6,29)$, lung cancer (30-34), hepatocellular cancer $(35,36)$, colorectal cancer $(37,38)$, prostate cancer $(39,40)$, bladder cancer (41) pancreatic cancer (42), laryngeal carcinoma (43), esophageal cancer $(44,45)$, NK-cell lymphoma (46) and tongue squamous cell carcinomas (47). In some types of cancers, high levels of miR-21 expression have been linked to poor prognosis $(25,30,47-49)$.

In this study, we used real-time fluorescent quantitative PCR detection of miR-21 expression and found augmented expression in breast cancer tissue compared to normal adjacent tissue. The increase in miR-21 expression was negatively associated with serum levels of FSH, HCG and prolactin, and positively associated with levels of estradiol and testosterone in patients with breast cancer. Moreover, our in vitro data demonstrated that miR-21 regulated the proliferation and migration potential of breast cancer cells. Taken together, our data indicate that miR-21 may play a role in breast cancer progression and that detection of miR-21 should be further evaluated as a biomarker for predicting the prognosis of breast cancer. Previous studies are consistent with our current data, suggesting that miR-21 acts as an oncogene in the regulation of breast cancer development and progression.

Current methods for investigating the role of miRNA first utilize a bioinformatics approach to identify possible target genes (50). The next step is to upregulate miRNA expression or inhibit miRNA activity in transfected cells and examine protein expression by target genes to verify the correlation of miRNA activity and target gene expression. In the present study, to understand the mechanisms by which miR-21 promotes cancer cell proliferation and metastasis in breast cancer, we identified STAT3 as a potential target of miR-21 using bioinformatic analyses. Furthermore, we used target gene prediction software to predict the target genes of miR-21 and observed two incomplete pairing sequences with miR-21 in the STAT3 3'UTR region.

The STAT family of transcription factors is localized in the cell cytoplasm, transducing extracellular signals and activating transcription in the nucleus. The STAT family has seven subtypes in animals (51-54). Under physiological conditions, the duration of STAT activation is short (55) as it is quickly inactivated by tyrosine phosphatase within the nucleus. It is then transferred back into the cytoplasm where it can be reactivated by phosphorylation. However, in a tumorigenic environment, STAT3 may be continuously activated to stimulate the transcription of target genes, resulting in malignant transformation that promotes proliferation, invasion, and apoptotic inhibition of tumor cells (56-60).

In the present study, the protein level of STAT3 and its phosphorylation status was detected by western blotting in MCF-7 and MDA-MB-231 breast cancer cells transfected with miR-21 mimics and a miR-21 inhibitor. Our results showed that miR-21 exerted negative control on STAT3 expression and phosphorylation. These results were surprising given that we had verified in vitro that miR-21 stimulated breast cancer cell proliferation and migration. Furthermore, we showed that proliferation and migration of breast cancer cells was reduced by inhibiting p-STAT3 with Stattic, consistent with the above 
conclusion that p-STAT3 promotes tumor development. We would therefore expect that negative control of STAT3 expression and activation by miR-21 would inhibit the tumorigenic activity of breast cancer cells, whereas our experimental results show otherwise. A possible explanation is that miR-21 may inhibit other tumor suppressor genes, which increases oncogenic activity and disguises the inhibitory effect of miR-21 on STAT3. It has been reported previously that miR-21 targets multiple tumor suppressor genes including $b c l-2, t p m 1, p d c d 4$, pten and maspin $(61,62)$. This suggests that miR-21 inhibits the expression of most tumor suppressor genes, although we did find that STAT3 acting as a cancer gene can be inhibited by miR-21. We speculate that the number of cancer genes inhibited by miR-21 is less than the number of tumor suppressor genes inhibited by miR-21. It is likely that miR-21 plays a significant role in the development of breast cancer, not by promoting or inhibiting tumor occurrence directly, but rather by binding to complementary sequences within the 3'UTR of target mRNA transcripts, leading to mRNA deadenylation, degradation and inhibition of translation.

The regulation of target genes by miRNA is undoubtedly a very complex network structure. In the same tumor cells, miRNA may inhibit both cancer genes as well as tumor suppressor genes. When suppression of cancer genes is dominant in tumor cells, miRNA will inhibit tumor development, and vice versa, when inhibition of tumor suppressor genes is dominant, miRNA will promote tumor development. The results of our study illustrate this possible dual role of miR-21 in the regulation of breast cancer cells.

\section{Acknowledgements}

This study was supported by the Foundation of the Jiangsu University for senior talented man (grant no. 11JDG0089), the innovation project of cultivating graduates of Jiangsu province (grant no. CXLX13_689), the Science Foundation of Kunshan (grant no. KS1331) and the innovation and entrepreneurship training project of Jiangsu Students (201521099025Y).

\section{References}

1. Justo N, Wilking N, Jönsson B, Luciani S and Cazap E: A review of breast cancer care and outcomes in Latin America. Oncologist 18: 248-256, 2013

2. Key TJ, Verkasalo PK and Banks E: Epidemiology of breast cancer. Lancet Oncol 2: 133-140, 2001.

3. Ambros V: microRNAs: Tiny regulators with great potential. Cell 107: 823-826, 2001.

4. de Moor CH, Meijer H and Lissenden S: Mechanisms of translational control by the 3' UTR in development and differentiation. Semin Cell Dev Biol 16: 49-58, 2005.

5. Lee RC, Feinbaum RL and Ambros V: The C. elegans heterochronic gene lin-4 encodes small RNAs with antisense complementarity to lin-14. Cell 75: 843-854, 1993.

6. Iorio MV, Ferracin M, Liu CG, Veronese A, Spizzo R, Sabbioni S, Magri E, Pedriali M, Fabbri M, Campiglio M, et al: MicroRNA gene expression deregulation in human breast cancer. Cancer Res 65: 7065-7070, 2005.

7. Croce CM: Causes and consequences of microRNA dysregulation in cancer. Nat Rev Genet 10: 704-714, 2009.

8. Esquela-Kerscher A and Slack FJ: Oncomirs - microRNAs with a role in cancer. Nat Rev Cancer 6: 259-269, 2006

9. He H, Jazdzewski K, Li W, Liyanarachchi S, Nagy R, Volinia S, Calin GA, Liu CG, Franssila K, Suster S, et al: The role of microRNA genes in papillary thyroid carcinoma. Proc Natl Acad Sci USA 102: 19075-19080, 2005.
10. Scott GK, Goga A, Bhaumik D, Berger CE, Sullivan CS and Benz CC: Coordinate suppression of ERBB2 and ERBB3 by enforced expression of micro-RNA miR-125a or miR-125b. J Biol Chem 282: 1479-1486, 2007.

11. Wu ZS, Wu Q, Wang CQ, Wang XN, Huang J, Zhao JJ, Mao SS, Zhang GH, Xu XC and Zhang N: miR-340 inhibition of breast cancer cell migration and invasion through targeting of oncoprotein c-Met. Cancer 117: 2842-2852, 2011.

12. Wang R, Wang ZX, Yang JS, Pan X, De W and Chen LB: MicroRNA-451 functions as a tumor suppressor in human non-small cell lung cancer by targeting ras-related protein 14 (RAB14). Oncogene 30: 2644-2658, 2011.

13. Zhang J, Guo H, Zhang H, Wang H, Qian G, Fan X, Hoffman AR, $\mathrm{Hu}$ JF and Ge S: Putative tumor suppressor miR-145 inhibits colon cancer cell growth by targeting oncogene Friend leukemia virus integration 1 gene. Cancer 117: 86-95, 2011.

14. Ma L, Young J, Prabhala H, Pan E, Mestdagh P, Muth D, TeruyaFeldstein J, Reinhardt F, Onder TT, Valastyan S, et al: miR-9, a MYC/MYCN-activated microRNA, regulates E-cadherin and cancer metastasis. Nat Cell Biol 12: 247-256, 2010.

15. Ma L, Teruya-Feldstein $J$ and Weinberg RA: Tumour invasion and metastasis initiated by microRNA-10b in breast cancer. Nature 449: 682-688, 2007.

16. Valastyan S, Reinhardt F, Benaich N, Calogrias D, Szász AM, Wang ZC, Brock JE, Richardson AL and Weinberg RA: A pleiotropically acting microRNA, miR-31, inhibits breast cancer metastasis. Cell 137: 1032-1046, 2009.

17. Tavazoie SF, Alarcón C, Oskarsson T, Padua D, Wang Q, Bos PD, Gerald WL and Massagué J: Endogenous human microRNAs that suppress breast cancer metastasis. Nature 451: 147-152, 2008.

18. Hanahan D and Weinberg RA: Hallmarks of cancer: The next generation. Cell 144: 646-674, 2011.

19. Chiang AC and Massagué J: Molecular basis of metastasis. N Engl J Med 359: 2814-2823, 2008.

20. Talmadge JE and Fidler IJ: AACR centennial series: the biology of cancer metastasis: historical perspective. Cancer Res 70: 5649-5669, 2010

21. Valastyan S and Weinberg RA: MicroRNAs: Crucial multitasking components in the complex circuitry of tumor metastasis. Cell Cycle 8: 3506-3512, 2009.

22. Liu K, Zhang C, Li T, Ding Y, Tu T, Zhou F, Qi W, Chen H and Sun X: Let-7a inhibits growth and migration of breast cancer cells by targeting HMGA1. Int J Oncol 46: 2526-2534, 2015.

23. Fujita S, Ito T, Mizutani T, Minoguchi S, Yamamichi N, Sakurai K and Iba H: miR-21 Gene expression triggered by AP-1 is sustained through a double-negative feedback mechanism. J Mol Biol 378: 492-504, 2008.

24. Dillhoff M, Liu J, Frankel W, Croce C and Bloomston M: MicroRNA-21 is overexpressed in pancreatic cancer and a potential predictor of survival. J Gastrointest Surg 12: 2171-2176, 2008.

25. Gao W, Yu Y, Cao H, Shen H, Li X, Pan S and Shu Y: Deregulated expression of miR-21, miR-143 and miR-181a in non small cell lung cancer is related to clinicopathologic characteristics or patient prognosis. Biomed Pharmacother 64: 399-408, 2010.

26. Griffin CA, Hawkins AL, Packer RJ, Rorke LB and Emanuel BS: Chromosome abnormalities in pediatric brain tumors. Cancer Res 48: 175-180, 1988

27. Kasahara K, Taguchi T, Yamasaki I, Kamada M, Yuri K and Shuin T: Detection of genetic alterations in advanced prostate cancer by comparative genomic hybridization. Cancer Genet Cytogenet 137: 59-63, 2002.

28. Wu GJ, Sinclair CS, Paape J, Ingle JN, Roche PC, James CD and Couch FJ: 17q23 amplifications in breast cancer involve the PAT1, RAD51C, PS6K, and SIGma1B genes. Cancer Res 60: 5371-5375, 2000.

29. Teng Y, Manavalan TT, Hu C, Medjakovic S, Jungbauer A and Klinge CM: Endocrine disruptors fludioxonil and fenhexamid stimulate miR-21 expression in breast cancer cells. Toxicol Sci 131: 71-83, 2013.

30. Yanaihara N, Caplen N, Bowman E, Seike M, Kumamoto K, Yi M, Stephens RM, Okamoto A, Yokota J, Tanaka T, et al: Unique microRNA molecular profiles in lung cancer diagnosis and prognosis. Cancer Cell 9: 189-198, 2006.

31. Yang M, Shen H, Qiu C, Ni Y, Wang L, Dong W, Liao Y and Du J: High expression of miR-21 and miR-155 predicts recurrence and unfavourable survival in non-small cell lung cancer. Eur J Cancer 49: 604-615, 2013. 
32. Markou A, Tsaroucha EG, Kaklamanis L, Fotinou M, Georgoulias V and Lianidou ES: Prognostic value of mature microRNA-21 and microRNA-205 overexpression in non-small cell lung cancer by quantitative real-time RT-PCR. Clin Chem 54: 1696-1704, 2008.

33. Cho WC, Chow AS and Au JS: Restoration of tumour suppressor hsa-miR-145 inhibits cancer cell growth in lung adenocarcinoma patients with epidermal growth factor receptor mutation. Eur J Cancer 45: 2197-2206, 2009.

34. Seike M, Goto A, Okano T, Bowman ED, Schetter AJ, Horikawa I, Mathe EA, Jen J, Yang P, Sugimura H, et al: MiR-21 is an EGFRregulated anti-apoptotic factor in lung cancer in never-smokers. Proc Natl Acad Sci USA 106: 12085-12090, 2009.

35. Meng F, Henson R, Wehbe-Janek H, Ghoshal K, Jacob ST and Patel T: MicroRNA-21 regulates expression of the PTEN tumor suppressor gene in human hepatocellular cancer. Gastroenterology 133: 647-658, 2007.

36. Bihrer V, Waidmann O, Friedrich-Rust M, Forestier N, Susser S, Haupenthal J, Welker M, Shi Y, Peveling-Oberhag J, Polta A, et al: Serum microRNA-21 as marker for necroinflammation in hepatitis $\mathrm{C}$ patients with and without hepatocellular carcinoma. PLoS One 6: e26971,2011.

37. Kanaan Z, Rai SN, Eichenberger MR, Roberts H, Keskey B, Pan J and Galandiuk S: Plasma miR-21: A potential diagnostic marker of colorectal cancer. Ann Surg 256: 544-551, 2012.

38. Wu CW, Ng SS, Dong YJ, Ng SC, Leung WW, Lee CW, Wong YN, Chan FK, Yu J and Sung JJ: Detection of miR-92a and miR-21 in stool samples as potential screening biomarkers for colorectal cancer and polyps. Gut 61: 739-745, 2012.

39. Li T, Li RS, Li YH, Zhong S, Chen YY, Zhang CM, Hu MM and Shen ZJ: miR-21 as an independent biochemical recurrence predictor and potential therapeutic target for prostate cancer. J Urol 187: 1466-1472, 2012.

40. Yang $\mathrm{CH}$, Yue J, Fan M and Pfeffer LM: IFN induces miR-21 through a signal transducer and activator of transcription 3 -dependent pathway as a suppressive negative feedback on IFN-induced apoptosis. Cancer Res 70: 8108-8116, 2010.

41. Catto JW, Miah S, Owen HC, Bryant H, Myers K, Dudziec E Larré S, Milo M, Rehman I, Rosario DJ, et al: Distinct microRNA alterations characterize high- and low-grade bladder cancer. Cancer Res 69: 8472-8481, 2009.

42. Moriyama T, Ohuchida K, Mizumoto K, Yu J, Sato N, Nabae T, Takahata S, Toma H, Nagai E and Tanaka M: MicroRNA-21 modulates biological functions of pancreatic cancer cells including their proliferation, invasion, and chemoresistance. Mol Cancer Ther 8: 1067-1074, 2009.

43. Liu M, Wu H, Liu T, Li Y, Wang F, Wan H, Li X and Tang H: Regulation of the cell cycle gene, BTG2, by miR-21 in human laryngeal carcinoma. Cell Res 19: 828-837, 2009.

44. Hiyoshi Y, Kamohara H, Karashima R, Sato N, Imamura Y, Nagai Y, Yoshida N, Toyama E, Hayashi N, Watanabe M, et al: MicroRNA-21 regulates the proliferation and invasion in esophageal squamous cell carcinoma. Clin Cancer Res 15: 1915-1922, 2009.

45. Alder H, Taccioli C, Chen H, Jiang Y, Smalley KJ, Fadda P, Ozer HG, Huebner K, Farber JL, Croce CM, et al: Dysregulation of miR-31 and miR-21 induced by zinc deficiency promotes esophageal cancer. Carcinogenesis 33: 1736-1744, 2012.
46. Yamanaka Y, Tagawa H, Takahashi N, Watanabe A, Guo YM, Iwamoto K, Yamashita J, Saitoh H, Kameoka Y, Shimizu N, et al: Aberrant overexpression of microRNAs activate AKT signaling via down-regulation of tumor suppressors in natural killer-cell lymphoma/leukemia. Blood 114: 3265-3275, 2009.

47. Li J, Huang H, Sun L, Yang M, Pan C, Chen W, Wu D, Lin Z, Zeng C, Yao Y, et al: MiR-21 indicates poor prognosis in tongue squamous cell carcinomas as an apoptosis inhibitor. Clin Cancer Res 15: 3998-4008, 2009.

48. Zaman MS, Shahryari V, Deng G, Thamminana S, Saini S, Majid S, Chang I, Hirata H, Ueno K, Yamamura S, et al: Up-regulation of microRNA-21 correlates with lower kidney cancer survival. PLoS One 7: e31060, 2012.

49. Gao W, Shen H, Liu L, Xu J, Xu J and Shu Y: MiR-21 overexpression in human primary squamous cell lung carcinoma is associated with poor patient prognosis. J Cancer Res Clin Oncol 137: 557-566, 2011

50. Bartel DP: MicroRNAs: Target recognition and regulatory functions. Cell 136: 215-233, 2009.

51. Horvath CM: STAT proteins and transcriptional responses to extracellular signals. Trends Biochem Sci 25: 496-502, 2000.

52. Shuai K: Modulation of STAT signaling by STAT-interacting proteins. Oncogene 19: 2638-2644, 2000.

53. Leaman DW, Leung S, Li X and Stark GR: Regulation of STATdependent pathways by growth factors and cytokines. FASEB J 10: 1578-1588, 1996.

54. Schindler $\mathrm{C}$ and Brutsaert $\mathrm{S}$ : Interferons as a paradigm for cytokine signal transduction. Cell Mol Life Sci 55: 1509-1522, 1999.

55. Bromberg JF: Activation of STAT proteins and growth control. BioEssays 23: 161-169, 2001.

56. Bowman T, Garcia R, Turkson J and Jove R: STATs in oncogenesis. Oncogene 19: 2474-2488, 2000.

57. Bromberg JF, Wrzeszczynska MH, Devgan G, Zhao Y, Pestell RG, Albanese C and Darnell JE Jr: Stat3 as an oncogene. Cell 98: 295-303, 1999.

58. Catlett-Falcone R, Landowski TH, Oshiro MM, Turkson J, Levitzki A, Savino R, Ciliberto G, Moscinski L, FernándezLuna JL, Nuñez G, et al: Constitutive activation of Stat 3 signaling confers resistance to apoptosis in human U266 myeloma cells. Immunity 10: 105-115, 1999.

59. Niu G, Wright KL, Huang M, Song L, Haura E, Turkson J, Zhang S, Wang T, Sinibaldi D, Coppola D, et al: Constitutive Stat3 activity up-regulates VEGF expression and tumor angiogenesis. Oncogene 21: 2000-2008, 2002.

60. Leong PL, Andrews GA, Johnson DE, Dyer KF, Xi S, Mai JC, Robbins PD, Gadiparthi S, Burke NA, Watkins SF, et al: Targeted inhibition of Stat 3 with a decoy oligonucleotide abrogates head and neck cancer cell growth. Proc Natl Acad Sci USA 100: 4138-4143, 2003

61. Wen YH, Shi X, Chiriboga L, Matsahashi S, Yee H and Afonja O: Alterations in the expression of PDCD4 in ductal carcinoma of the breast. Oncol Rep 18: 1387-1393, 2007.

62. Davis BN, Hilyard AC, Lagna G and Hata A: SMAD proteins control DROSHA-mediated microRNA maturation. Nature 454 56-61, 2008. 